J. Asiat. Soc. Bangladesh, Sci. 39(2): 183-190, December 2013

\title{
ELECTROSYNTHESIS OF Cu / ZnO NANOCOMPOSITE ELECTRODE ON ITO ELECTRODE AND ITS APPLICATION IN OXIDATION OF ASCORBIC ACID AND GLUCOSE
}

\author{
M. EMRAN QUAYUM, BABLU BISWAS AND MD. KHAIRUL HASSAN BHUIYAN ${ }^{1}$ \\ Department of Chemistry, University of Dhaka, Dhaka-1000 \\ ${ }^{1}$ Department of Physics, Faculty of Agriculture, BAU, Mymensingh
}

\begin{abstract}
In the present study $\mathrm{Cu}$ nanoparticles (NPs), $\mathrm{ZnO}$ nanorods have been deposited on indium tin oxide (ITO) electrode and thereby Cu-NPs /ZnO / ITO composite film electrode has been prepared. The prepared nanostructures have been characterized by using scanning electron microscope (SEM). The shape of the electrochemically deposited $\mathrm{ZnO}$ follow rod like structure on ITO electrode, $\mathrm{Cu}-\mathrm{NPs}$ follow irregular spherical shape when electrodeposited on ITO electrode. Oxidation of ascorbic acid on bare ITO electrode is favorable than that of $\mathrm{ZnO}$ modified ITO electrode but $\mathrm{Cu}-\mathrm{NPs} /$ $\mathrm{ZnO}$ composite electrode had high sensitivity and stability and showed higher catalytic current for glucose oxidation.
\end{abstract}

Key words: Nanoparticles (NPs), Nanocomposite electrode, Indium tin oxide (ITO), Ascorbic acid, Glucose

\section{Introduction}

Electrochemical sensors and biosensors for the electroanalysis of biologically active compounds have attracted a great deal of interest due to their analytical performances (Xu et al. 2006). Electrochemical sensors provide low detection limits, a wide linear response range, and good stability and reproducibility, among other advantages (Zhang et al. 1997 and Chen et al. 2008). However, bare electrodes are more likely than chemically modified electrodes to suffer from interferences or surface fouling by products arising from follow-up reactions, associated to the main electrochemical process. The modification of electrode surfaces with inorganic or organic coatings often avoids these drawbacks and represents a rapid and versatile resource for the preparation of stable and selective new electrochemical sensors (Evans et al. 2004 and Wang 2008).

Electrochemical methods have potential application in the detection of D (+)-glucose in blood samples (Wilson and Turner 1992) and also in bio-fuel cells (Park el al. 2006). Glucose oxidase (GOD) is one of the most extensively studied enzyme and has been successfully employed for preparing glucose biosensors. The development of glucose biosensors utilizing GOD is an active research area (Chen et al. 2002, Evans et al. 2004 and Wang 2008). A majority of glucose sensors, especially those used in in-vivo application are based on the electrochemical oxidation of hydrogen peroxide which is formed in the course of the enzyme-catalyzed oxidation of glucose by dissolved oxygen.

\footnotetext{
${ }^{1}$ Corresponding author: Email: relyeq@gmail.com
} 
Recently, excellent review articles have been published and discussed about the principles of electrochemical glucose biosensors and key challenges in their further development and use. It is shown that nano- $\mathrm{ZnO}$ film provides better environment and enhanced electron transfer between ChOx and electrode (Lupo et al. 2010).

Over the past decades, a number of studies have been conducted to alleviate the drawbacks of enzymatic glucose sensors. The most common and serious problem is insufficient stability originated from the nature of the enzymes which is hardly overcome. Although glucose oxidase (GOD) is quite stable compared with other enzymes, the glucose sensors based on GOD are always exposed to the possible thermal and chemical deformation during fabrication, storage or use. Further, GOD quickly loses its activity below pH 2 and above $\mathrm{pH} 8$ and temperature above $40{ }^{\circ} \mathrm{C}$ can cause fatal damages (Wilson and Turner 1992). Ionic detergents also deactivate GOD as well. To overcome the above obstacles, non-enzymatic glucose sensors have been developed and kept coming closer to practical applications. Park and coworkers discussed about the merits and mechanism of glucose oxidation on non-enzymatic sensors (Park et al. 2006). Nanostructured particles have attracted extensive scientific and industrial interest due to their unique electronic, optical and catalytic properties. Nanoparticles can display four unique advantages over microelectrodes when used for electro analysis. These are: enhancement of mass transport, catalysis, high effective surface area and control over electrode microenvironment (Lupo et al. 2010). Electrochemical deposition of copper nanoparticles (Cu-NPs) and their applications in electro-catalysis is an active research area (Miao et al. 2008). Though, the Cu-NPs were prepared in several matrixes by several researchers, no effort has been made to prepare $\mathrm{Cu}-\mathrm{NPs}$ embedded in functional matrix material like zinc oxide $(\mathrm{ZnO})$. In our laboratory zinc oxide $(\mathrm{ZnO})$ nano particles have been prepared by using simple combustion methods and by electrochemical methods onto ITO electrode in order to use as nano-electrodes. In the present study, $\mathrm{ZnO}$ NPs were deposited on the ITO electrodes by electrochemical method. Copper NPs were deposited onto $\mathrm{ZnO} / \mathrm{ITO}$ electrode to obtain $\mathrm{Cu}-\mathrm{NPs} / \mathrm{ZnO} / \mathrm{ITO}$ composite film electrode using electrochemical technique. The characterization of these electrodes have been performed by using SEM and possible applications of these electrodes as sensors have been examined by using electrochemical methods.

\section{Materials and Methods}

This research work was carried out at the physical chemistry research laboratory, Dhaka University, during the period of 2010.

Chemicals: Potassium chloride, $\mathrm{KCl}$ (BDH. UK), zinc nitrate, $\mathrm{Zn}\left(\mathrm{NO}_{3}\right)_{2} \cdot 6 \mathrm{H}_{2} \mathrm{O}$ (MERCK, India), zinc acetate, $\mathrm{Zn}\left(\mathrm{CH}_{3} \mathrm{COO}\right)_{2} \cdot 2 \mathrm{H}_{2} \mathrm{O}$ (MERCK, Germany), copper sulfate, $\mathrm{CuSO}_{4} .5 \mathrm{H}_{2} \mathrm{O}$ (MERCK, Germany), absolute ethyl alcohol, (AR, BDH), ethylene glycol (AR, BDH), sodium hydroxide, $\mathrm{NaOH}(\mathrm{AR}, \mathrm{BDH}), \mathrm{N}_{2}, 99.99 \%$ pure (BOC, Bangladesh), sulfuric acid, $\mathrm{H}_{2} \mathrm{SO}_{4}(\mathrm{AR}, \mathrm{BDH})$, potassium per chlorate, $\mathrm{KClO}_{4}(\mathrm{AR}, \mathrm{BDH})$, Glucose, 
$\mathrm{C}_{6} \mathrm{H}_{12} \mathrm{O}_{6}(\mathrm{AR}, \mathrm{BDH})$, cetyltrimethyl ammonium bromide (CTAB) (BDH, UK), ascorbic acid, $\left(\mathrm{C}_{6} \mathrm{H}_{8} \mathrm{O}_{6}\right)$, (Merck, Germany) and potassium ferricyanide, $\mathrm{K}_{3} \mathrm{Fe}(\mathrm{CN})_{6}$ (Merck, Germany) were used without further purification.

Instruments: A Computerized Electrochemistry system, Model HQ 2040 was used in the present study. A pyrex glass volumetric cell $(10 \mathrm{~mL})$ with three electrode configurations, ITO as working electrode (area $3.2 \mathrm{~cm}^{2}$ ), platinum wire as the counter electrode and $\mathrm{Ag} / \mathrm{AgCl}$ (satd. $\mathrm{KCl}$ ) as the reference electrode was used in this study.

SEM (Hitachi, S-3400, Japan) was used in this experiment. In this SEM accelerating voltage was fixed ranging from $0.3 \mathrm{kV}$ to $30.0 \mathrm{kV}$. Resolution was set in $3.0 \mathrm{~nm}$ at 30.0 $\mathrm{kV}$ accelerating voltage in high vacuum mode for Secondary Electron (SE) image. Back Scattered Electron (BSE) image resolution was set in $4.0 \mathrm{~nm}$ at $30.0 \mathrm{kV}$ accelerating voltage in low vacuum mode. For all these images magnification was set at a range 5 times to 300000 times. From this SEM image size and different shapes of nanoparticles were characterized.

Supporting electrolyte solution:

(a) $100 \mathrm{~mL}$ of $0.1 \mathrm{M} \mathrm{KCl}$ solution was prepared in deionized water.

(b) $100 \mathrm{~mL}$ of $0.1 \mathrm{M} \mathrm{NaOH}$ solution was prepared in deionized water.

(c) $\mathrm{CuSO}_{4} \cdot 5 \mathrm{H}_{2} \mathrm{O}$ solution: $10 \mathrm{~mL}$ of $0.1 \mathrm{M} \mathrm{Cu}^{2+}$ stock solution was prepared in $0.1 \mathrm{M} \mathrm{KCl}$.

(d) $\mathrm{K}_{3} \mathrm{Fe}(\mathrm{CN})_{6}$ solution: $10 \mathrm{~mL}$ of $0.1 \mathrm{M} \mathrm{K}_{3} \mathrm{Fe}(\mathrm{CN})_{6}$ solution was prepared in $0.1 \mathrm{M} \mathrm{KCl}$.

(e) Glucose solution: $10 \mathrm{~mL}$ of glucose solution was prepared in $0.1 \mathrm{M} \mathrm{NaOH}$.

(f) Ascorbic acid solution: $10 \mathrm{~mL}$ of $0.1 \mathrm{M}$ Ascorbic acid stock solution was prepared in $0.1 \mathrm{M} \mathrm{KCl}$.

Electrochemical Method for the preparation of $\mathrm{ZnO}$ NPs:The conventional three electrode cell in which $\mathrm{ZnO}$ NPs were prepared was maintained at $40^{\circ} \mathrm{C}$ in a water bath. The working electrode was a commercial ITO glass $(30 \times 66.66 \times 6 \mathrm{~mm}, \mathrm{R}(\mathrm{s})<10 \mathrm{ohm})$. An aqueous solution of $0.1 \mathrm{M} \mathrm{Zn}\left(\mathrm{NO}_{3}\right)_{2}$ mixed with $0.1 \mathrm{M} \mathrm{KCl}$ was used and deposition was carried out for an hour. $\mathrm{ZnO}$ nanoparticles were electrodeposited on ITO electrode at $-1.1 \mathrm{~V}$ vs. $\mathrm{Ag} / \mathrm{AgCl}$ reference electrode and a Pt electrode was used as counter electrode. After deposition the resulting nanodeposits were thoroughly rinsed with water and dried under a nitrogen atmosphere.

\section{Results and Discussion}

Preparation of copper nanoparticles/zinc oxide composite modified electrode: ITO substrates were cleaned by using detergent, diluted hydrochloric acid and then finally rinsed with distilled water. Transparent $\mathrm{ZnO}$ films have been cathodically deposited onto conductive ITO glasses from a simple aqueous zinc nitrate electrolyte bath kept at $335 \mathrm{~K}$. Electrodeposition of $\mathrm{ZnO}$ film was carried out potentiostatically $(-0.7 \mathrm{~V}$ for $20 \mathrm{~min}$ ) 
using a potentio/ galvanostat without stirring. ZnO-modified ITO was rinsed with distilled water to remove unbounded materials from the electrode surface and then dried by nitrogen gas. $\mathrm{Cu}-\mathrm{NPs}$ were deposited onto a $\mathrm{ZnO}$ film coated ITO from the solutions of $0.01 \mathrm{M} \mathrm{CuSO}_{4}+0.1 \mathrm{M} \mathrm{KClO}_{4}$ under fixed applied potential of $-0.9 \mathrm{~V}$ (vs. $\mathrm{Ag} / \mathrm{AgCl}$ ) for $3 \mathrm{~min}$. For comparative studies, Cu-NPs were deposited onto an unmodified ITO as described above. Finally, the $\mathrm{Cu}-\mathrm{NPs} / \mathrm{ZnO}$ composite modified electrode was thoroughly washed with doubly distilled water to remove unbounded materials from the electrode surface and then dried in air for $30 \mathrm{~min}$ before use.

SEM images of $\mathrm{ZnO}$ nanoparticles:It is not possible to determine the exact particle size from SEM images which can be done through TEM analysis. The SEM images show the approximate concept about the formation of nanoparticles.

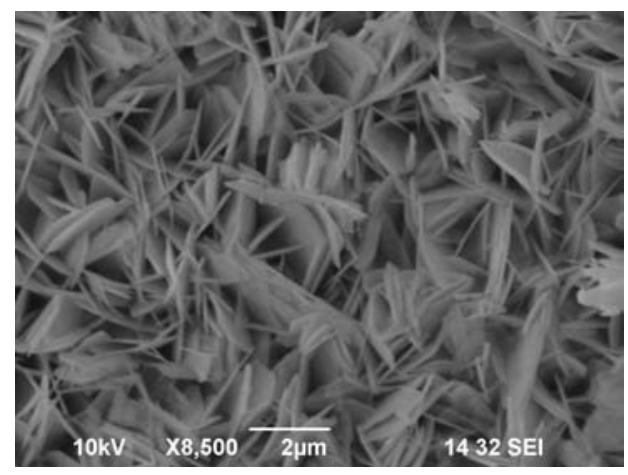

Fig. 1 (a) SEM image of ZnO NPs on ITO.

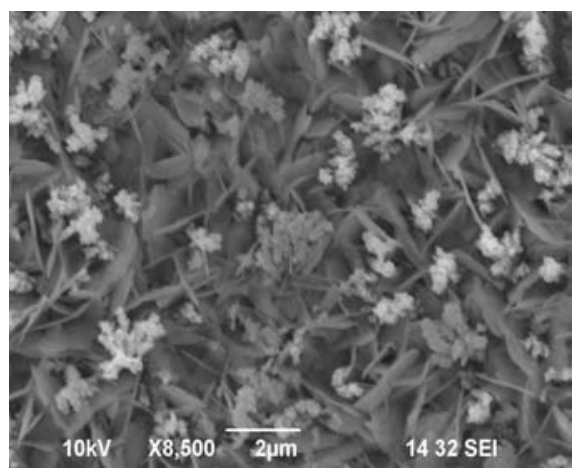

Fig. 1 (b) SEM image of $\mathrm{Cu} / \mathrm{ZnO}$ NPs on ITO.

Fig. 1 shows the SEM images of (a) ZnO deposited on ITO electrode and (b) Cu particles formed on $\mathrm{ZnO} / \mathrm{ITO}$ electrode. It is evident from above figures that $\mathrm{ZnO}$ NPs prepared by electrochemical methods on ITO electrode exhibits a rod like structures. ZnO NPs modified ITO electrode can be used as nanoelectrode. $\mathrm{Cu}$ NPs when deposited electrochemically on these modified electrode follow irregular flower like structures as shown in Fig. 1 (b). ZnO / ITO electrode and $\mathrm{Cu}$ NPs / ZnO / ITO composite film electrodes have been used in the present study as sensors.

Electrochemical behaviour of $\mathrm{K}_{3} \mathrm{Fe}(\mathrm{CN})_{6}$ on ITO electrode for different scan rates: Fig.2 shows the $\mathrm{CV}$ of $0.40 \mathrm{mM} \mathrm{K}_{3} \mathrm{Fe}(\mathrm{CN})_{6}$ solution at different scan rates on ITO electrode. The potential was stepped from $+0.650 \mathrm{~V}$ to a vertex potential of $-0.150 \mathrm{~V}$ and finally the potential was reversed back to $+0.650 \mathrm{~V}$. The cathodic peak was observed at $+0.158 \mathrm{~V}$. The corresponding anodic peak was observed at $+0.230 \mathrm{~V}$. Both cathodic and anodic peak current increases with increasing scan rate and potential remain almost constant. 


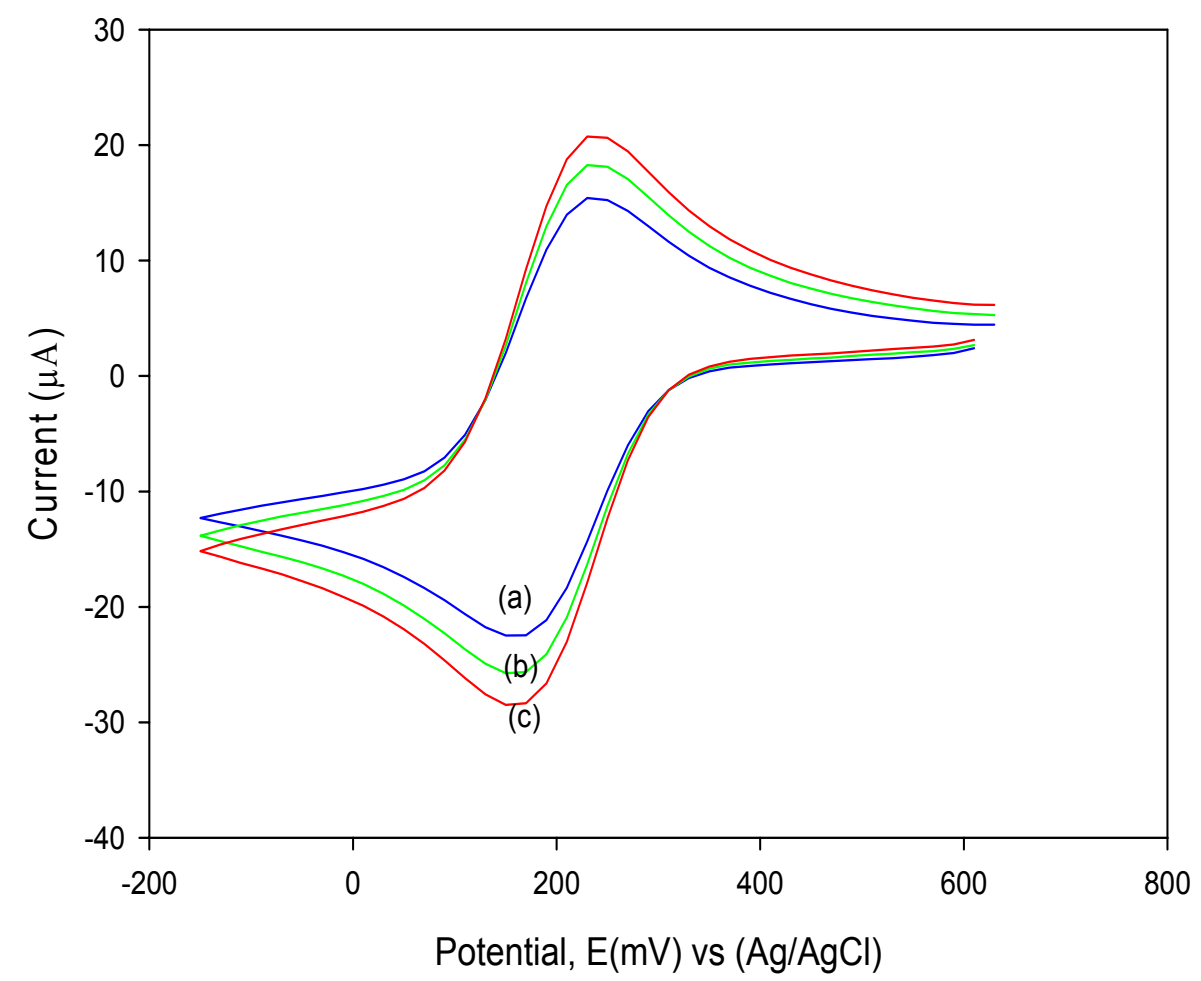

Fig. 2. $\mathrm{CV}$ of $0.40 \mathrm{mM} \mathrm{K}_{3} \mathrm{Fe}(\mathrm{CN})_{6}$ solution at (a) $15 \mathrm{mVs}^{-1}$ (b) $20 \mathrm{mVs}^{-1}$ (c) $25 \mathrm{mVs}^{-1} \mathrm{~S} . \mathrm{R}$.

Electrochemical behaviour of $\mathrm{K}_{3} \mathrm{Fe}(\mathrm{CN})_{6}$ on $\mathrm{ZnO}$ Modified ITO electrode for different scan rates : Fig. 3. Shows the $\mathrm{CV}$ of $0.40 \mathrm{mM} \mathrm{K}{ }_{3} \mathrm{Fe}(\mathrm{CN})_{6}$ solution at different scan rates on modified ITO electrode. The potential was stepped from $+0.650 \mathrm{~V}$ to a vertex potential of $-0.150 \mathrm{~V}$ and finally the potential was reversed back to $+0.650 \mathrm{~V}$. The cathodic peak was observed at $+0.162 \mathrm{~V}$. The corresponding anodic peak was observed at $+0.245 \mathrm{~V}$. Both cathodic and anodic peak current increases with increasing scan rate and potential remain almost constant.

Comparison of $\mathrm{CV}$ of $\mathrm{K}_{3}\left[\mathrm{Fe}(\mathrm{CN})_{6}\right]$ solution between ITO electrode and $\mathrm{ZnO}$ modified ITO electrode : Here the $\mathrm{CV}$ of $\mathrm{K}_{3}\left[\mathrm{Fe}(\mathrm{CN})_{6}\right]$ solutions (Fig. 4.) show that both the cathodic and anodic peak potential are almost at the same position for ITO electrode and modified ITO electrode. 


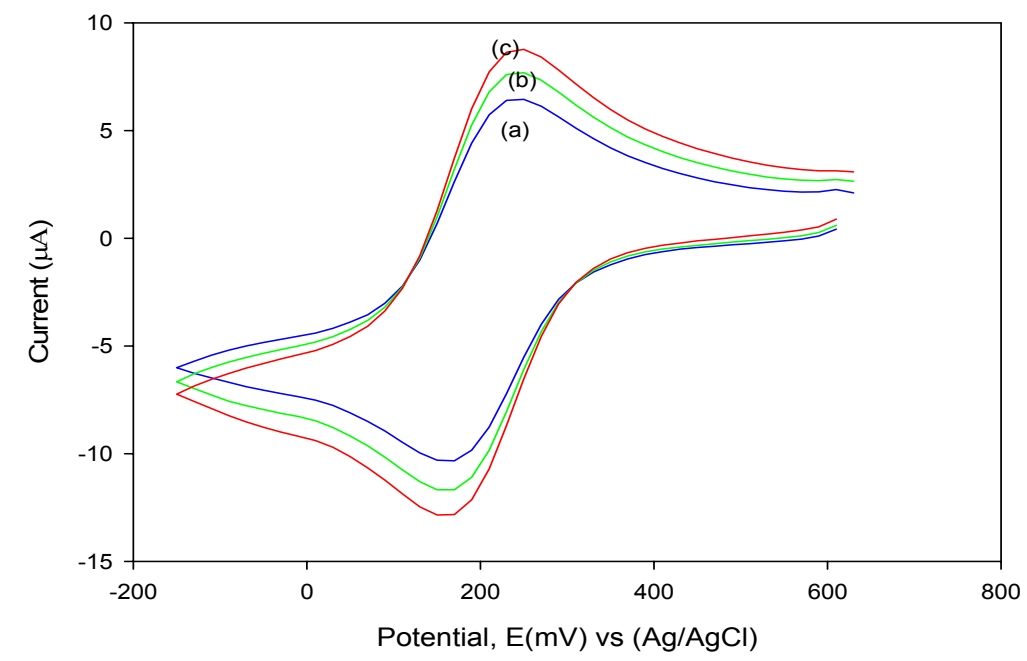

Fig.3. $\mathrm{CV}$ of $0.40 \mathrm{mM} \mathrm{K}_{3} \mathrm{Fe}(\mathrm{CN})_{6}$ solution at (a) $15 \mathrm{mVs}^{-1}$ (b) $20 \mathrm{mVs}^{-1}$ (c) $25 \mathrm{mVs}^{-1}$ S.R.

But the current decreases significantly in the case of $\mathrm{ZnO}$ modified ITO electrode. The diffusion coefficient values were found as follows:

(a) The Diffusion co-efficient at ITO electrode $=13.03 \times 10^{-8} \mathrm{~cm}^{2} / \mathrm{s}$

(b) The Diffusion co-efficient at ZnO modified ITO electrode $=2.22 \times 10^{-8} \mathrm{~cm}^{2} / \mathrm{s}$.

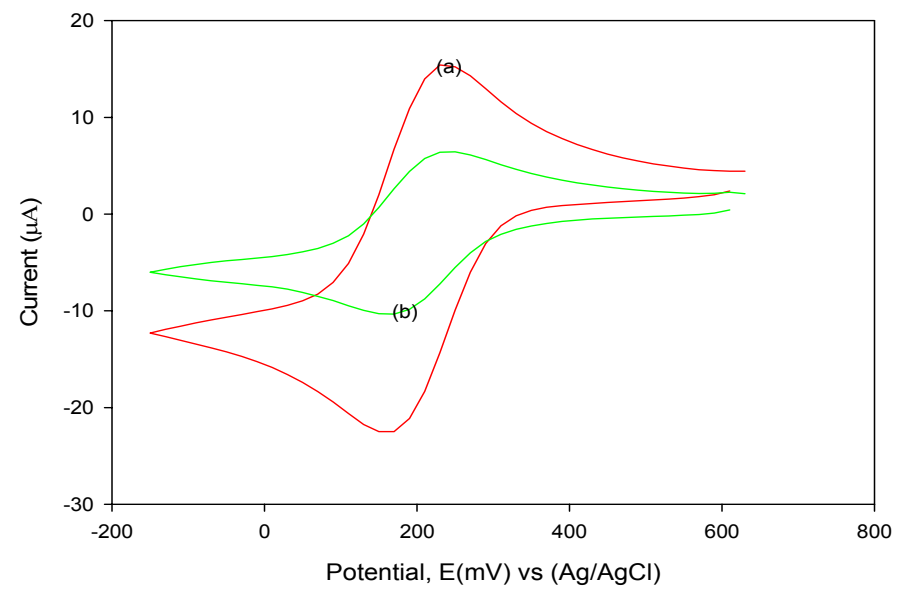

Fig.4. $\mathrm{CV}$ of $0.40 \mathrm{mM} \mathrm{K} \mathrm{K}_{3}\left[\mathrm{Fe}(\mathrm{CN})_{6}\right]$ solution at (a) ITO electrode (b) $\mathrm{ZnO}$ modified ITO electrode at scan rate $15 \mathrm{mVs}^{-1}$. 
Oxidation of glucose on ITO, $\mathrm{ZnO} /$ ITO and $\mathrm{Cu}$ NPs/ $\mathrm{ZnO} /$ ITO composite electrode: From Fig. 5. it is evident that glucose exhibits an oxidation peak at around $+0.8 \mathrm{~V}$ on ITO electrode (curve c) the peak current decreases when the $\mathrm{CV}$ is run on $\mathrm{ZnO}$ modified ITO electrode. However, the glucose oxidation enhances remarkably when the CV is carried out onto $\mathrm{Cu} \mathrm{NP/} \mathrm{ZnO/} \mathrm{ITO} \mathrm{composite} \mathrm{electrode.} \mathrm{The} \mathrm{peak} \mathrm{current} \mathrm{for} \mathrm{glucose} \mathrm{oxidation}$ increases almost ten times indicating that $\mathrm{Cu}$ NPs play a strong catalytic role when deposited onto $\mathrm{ZnO}$ particles. $\mathrm{CVs}$ of the $\mathrm{Cu} \mathrm{NPs} / \mathrm{ZnO}$ composite modified electrode recorded in $0.1 \mathrm{M} \mathrm{NaOH}$ in the presence (curve a) and absence (curve b) of $5 \mathrm{mM}$ glucose. It exhibited a single oxidation peak around 0.4 to $0.8 \mathrm{~V}$ vs $\mathrm{Ag} / \mathrm{AgCl}$. Fig.5 (curve $\mathrm{c}$ and $\mathrm{d}$ ) shows CVs obtained for glucose at a bare ITO electrode (curve c) and a $\mathrm{ZnO}$ modified electrode (curve d).

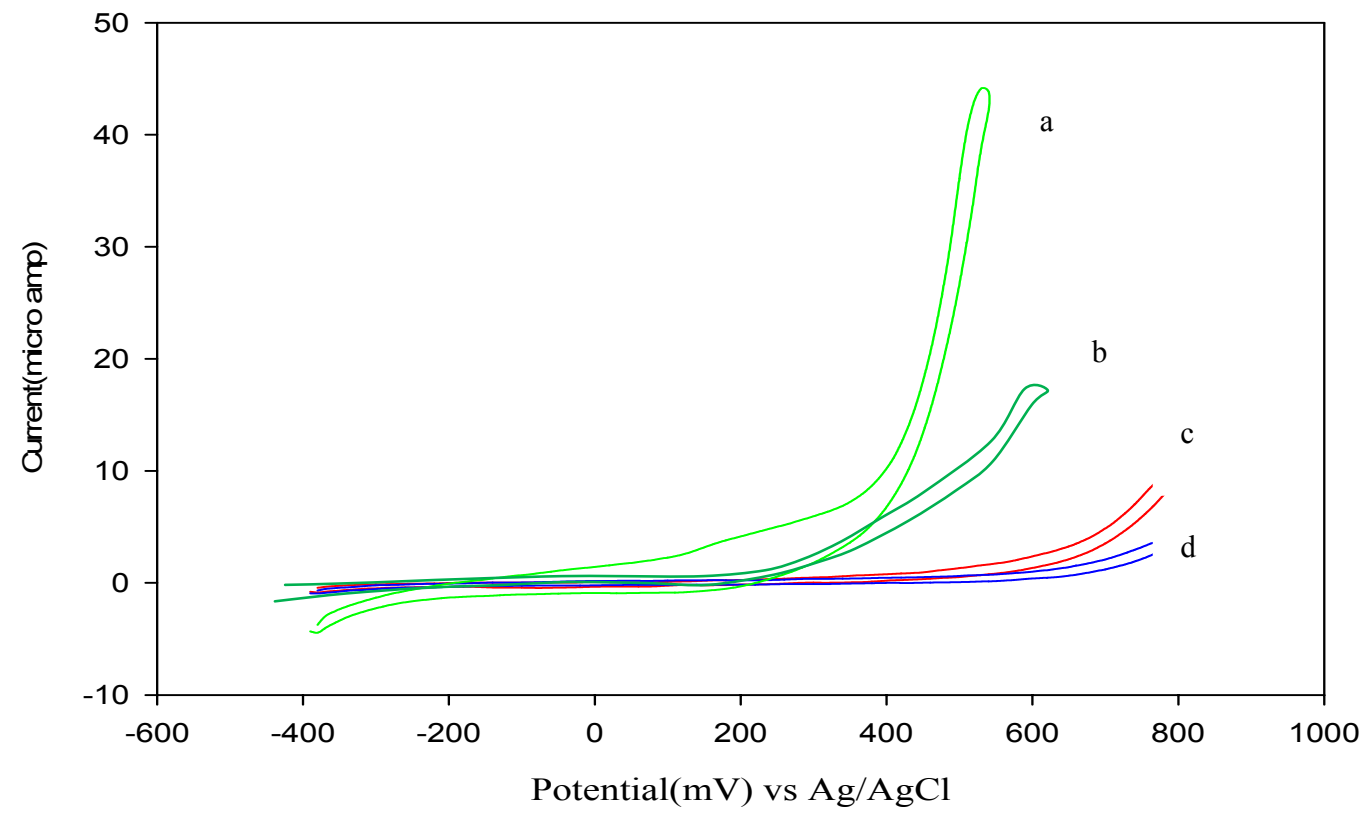

Fig. 5. The CVs of $5 \mathrm{mM}$ glucose in $0.1 \mathrm{M} \mathrm{NaOH}$ solution at $\mathrm{Cu}-\mathrm{NPs} / \mathrm{ZnO} /$ ITO composite electrode (a) $\mathrm{CV}$ without glucose (curve b) The CVs of $5 \mathrm{mM}$ glucose in $0.1 \mathrm{M} \mathrm{NaOH}$ solution at bare ITO (curve c) and at $\mathrm{ZnO} / \mathrm{ITO}$ (curve d) at a scan rate of $20 \mathrm{mV} \mathrm{s}^{-1}$.

In this study $\mathrm{ZnO}$ nanostructures and $\mathrm{Cu}-\mathrm{NPs}$ have been deposited onto ITO electrode by using electrochemical method. It was found that $\mathrm{Cu}-\mathrm{NPs} / \mathrm{ZnO}$ composite modified electrode exhibits higher electrocatalytic activity towards glucose oxidation. The obtained results revealed that determination of glucose can be easily performed using $\mathrm{Cu}-\mathrm{NPs} / \mathrm{ZnO}$ composite film electrode and the modified electrode enhanced the eletrocatalytic activity remarkably towards glucose with high stability in its solution. The $\mathrm{Cu}-\mathrm{NPS}, \mathrm{ZnO}$ nanostructures and composite electrodes were characterized by SEM and CV. This method may open an avenue for electrochemical sensing of glucose, ascorbic acid, other 
biomolecules and organic pollutants present in the environment. Further study for the development of non enzymatic electrochemical sensors is in progress.

\section{References}

Chen, X.H., Y.B. Hu and G.S. Wilson. 2002. Glucose microbiosensor based on alumina sol-gel metrix/electropolymerized composite membrane. Biosens. Bioelectron. 17 : 1005-1008.

Chen, X., J. Chen, C. Deng, C. Xiao, Y. Yang, Z. Nie and S. Yao. 2008. Amperometric Glucose biosensor based on boron -doped carbon nanotubes modified electrode. Talanta. 76 : 763-768.

Evans , R.G., C.E. Banks and R.G. Compton. 2004. Amperometric detection of glucose using self catalytic carbon paste electrode. Analyst. 129: 428-433.

Lupu, S., F. J. Del Campo and F. Xavier Muñoz. 2010. Development of microelectrodearrays modified with inorganic-organic composite materials for dopamine electroanalysis. Electroanal. Chem. 639: 147-153.

Miao, X.M. , R. Yuan, Y.Q. Chai, Y.T. Shi and Y.Y. Yuan. 2008. Direct electrocatalytic reduction of hydrogen peroxide based on nfion and copper oxide nanoparticles modified $\mathrm{Pt}$ electrode. J. Electroanal. Chem. $612: 157-162$.

Park, S., H. Boo and T.D. Chung. 2006.Electrochemical non-enzymatic glucose sensors. Anal. Chim. Acta. 556: 46-52.

Wang, J. 2008. In vivo glucose monitoring: Towards 'sense and act' feedback- loop individualized medical systems. Talanta . 75: 636-642.

Wang, J. 2008. Electrochemical Glucose Biosensors. Chem. Rev. 108: 814-825.

Wang, J., G. Chen, M. Wang and M.P. Chatrathi. 2004. Carbon nanotube / copper composite electrodes for electrophoresis microchip detection of carbohydrates. Analyst. 129 : 512 516.

Wilson, R. and A.P.F. Turner. 1992. Glucose oxidase: an ideal enzyme. Biosens. Bioelectron. 7 : 165-169.

Xu, Q. , Y. Zhao, J.Z. Xu and J.J. Zhu. 2006. Preparation of functionalized copper nanoparticles and fabrication of glucose sensor. Sens. Actuators B. 114: 379-384.

Zhang, X. , K.Y. Chan, J.K. You, Z.G. Lin and A.C.C. Tseung. 1997. Partial oxidation of glucose by a $\mathrm{Pt} / \mathrm{WO}_{3}$ electrode. J. Electroanal. Chem. 430: 147-151.

(Received revised manuscript on 14 November 2013) 